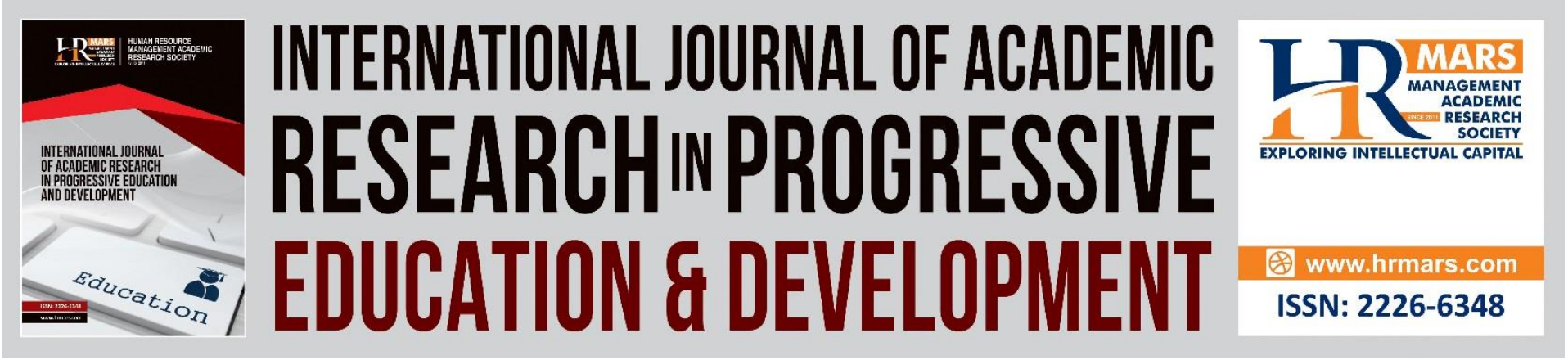

\title{
Motivational Facets, Edu-Tourist and Institutional Physiognomies, And Destination Selection Behaviour in An Augmented S-O-R Model: A Conceptual Review
}

Alfian Thomas, Hassnah Wee, Faiz Izwan Anuar, Norliza Aminudin

To Link this Article: http://dx.doi.org/10.6007/IJARPED/v10-i3/11360

DOI:10.6007/IJARPED/v10-i3/11360

Received: 15 August 2021, Revised: 18 September 2021, Accepted: 30 September 2021

Published Online: 20 November 2021

In-Text Citation: (Thomas et al., 2021)

To Cite this Article: Thomas, A., Wee, H., Anuar, F. I., \& Aminudin, N. (2021). Motivational Facets, Edu-Tourist and Institutional Physiognomies, And Destination Selection Behaviour in An Augmented S-O-R Model: A Conceptual Review. International Journal of Academic Research in Progressive Education and Development, 10(3), 1302-1320.

Copyright: (C) 2021 The Author(s)

Published by Human Resource Management Academic Research Society (www.hrmars.com)

This article is published under the Creative Commons Attribution (CC BY 4.0) license. Anyone may reproduce, distribute, translate and create derivative works of this article (for both commercial and non-commercial purposes), subject to full attribution to the original publication and authors. The full terms of this license may be seen

at: http://creativecommons.org/licences/by/4.0/legalcode

Vol. 10(3) 2021, Pg. 1302 - 1320

http://hrmars.com/index.php/pages/detail/IJARPED

JOURNAL HOMEPAGE

Full Terms \& Conditions of access and use can be found at http://hrmars.com/index.php/pages/detail/publication-ethics 


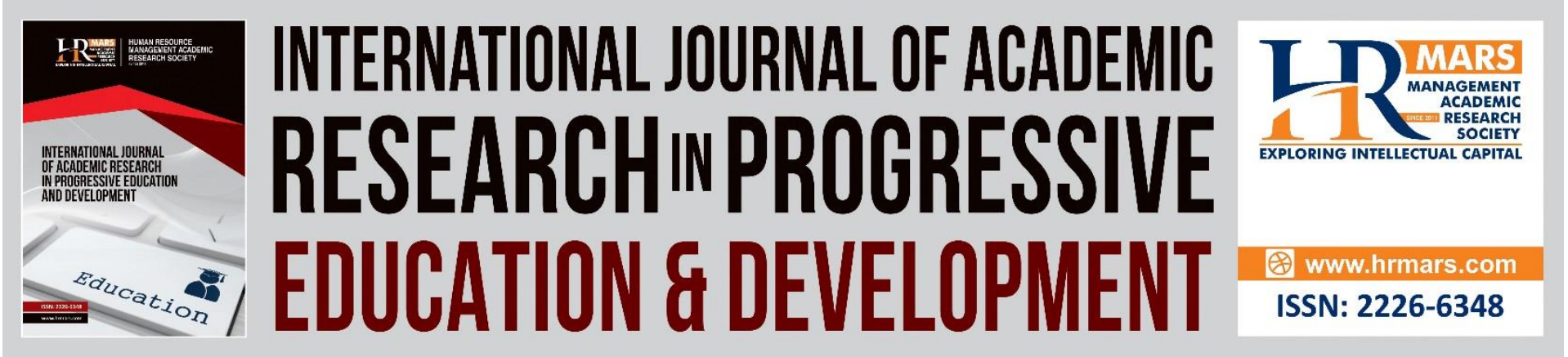

\title{
Motivational Facets, Edu-Tourist and Institutional Physiognomies, And Destination Selection Behaviour in An Augmented S-O-R Model: A Conceptual Review
}

\section{Alfian Thomas ${ }^{1}$, Hassnah Wee ${ }^{2}$, Faiz Izwan Anuar², Norliza Aminudin ${ }^{2}$}

${ }^{1}$ Department of Polytechnic and Community College Education Malaysia, Ministry of Higher Education, 62200 Putrajaya, Malaysia, ${ }^{2}$ Faculty of Hotel \& Tourism Management, Universiti

Teknologi MARA, Cawangan Selangor, 42300 Bandar Puncak Alam, Selangor, Malaysia Email: hassnah739@uitm.edu.my

\begin{abstract}
International students' enrollment in public and private educational institutions has declined due to the Novel Corona Virus 2019 (Covid-19) epidemic. The educational tourism business can profit more if service providers and regulators take a more proactive approach to studying educational tourist behavior in the face of pandemic-related challenges. The purpose of this study is to determine whether educational tourism and institutional physiognomies affect the link between motivational dimensions and destination selection behavior using an augmented Stimuli-Organism-Response (S-O-R) model. Through a review of different works of literature from several fields, this paper analyses the issues and aims of the impending study. The review's findings suggested a conceptual framework for future research that would expand the S-O-R model by examining the interaction between educational tourist motivational features from the Self-Determination Theory (SDT), educational tourist and institution physiognomies, and destination selection behavior. The suggested augmented S-O-R framework will substantially impact the relevant body of knowledge, and the future outcomes will help higher education institutions' strategies for attracting international students' enrollment.
\end{abstract}

Keywords: Educational Tourism, Motivation Facet, Institutional Physiognomies, Destination Selection Behaviour, Augmented S-O-R Model

\section{Introduction}

Globalization and the deregulation of the education sector have driven the rise of the Malaysian education market. As a result of these worldwide needs, the number of international students enrolled in tertiary education has increased. The combination of tourism and education has improved the tourism industry's performance (Rahman et al., 
2021). It has been defined as a program involving participants moving to a location either individually or in a group with the main primary objective of engaging in or having a learning experience (Carvalho, 2021). In Malaysia, educational tourism is growing in popularity, becoming a global hub for higher education for tertiary students (Bernama, 2019). However, on January 25, 2020, a new virus known as novel coronavirus or COVID-19 was discovered in Malaysia (Foo et al., 2020), which was caused by the Chinese people entered the nation via Singapore on January 23, 2020. The Prime Minister of Malaysia has issued the Movement Control Order (MCO) 1.0, which went into effect immediately to contain the virus. The number of COVID-19 cases continues to rise, and MCO 3.0 took place on May 25, 2021. This scenario has become a significant danger to the Visit Malaysia 2020 (VM2020) campaign, which began in December 2019. It has consistently resulted in a substantial decrease in the number of international visitors visiting Malaysia. The statistics of international tourist arrivals in 20162020 are shown in Table 1.

Table 1: International Tourist Arrivals 2016-2020

\begin{tabular}{|c|c|c|}
\hline Year & $\begin{array}{c}\text { Arrivals } \\
\text { (million) }\end{array}$ & $\begin{array}{c}\text { Receipts (RM) } \\
\text { (billion) }\end{array}$ \\
\hline 2020 & 4.33 & 12.69 \\
\hline 2019 & 26.10 & 86.1 \\
\hline 2018 & 25.83 & 84.1 \\
\hline 2017 & 25.95 & 82.1 \\
\hline 2016 & 26.76 & 82.1 \\
\hline
\end{tabular}

Source: Ministry of Tourism, Arts and Culture Malaysia (2021)

Accordingly, the number of international tourist arrivals was inconsistent in 2016 until 2018 with a growth of $1.04 \%$ in 2019 , followed by the increase in the number of international tourist arrivals from 25.83 million in 2018 to 26.10 million, keeping Malaysia as one of the top-ranked tourists' destinations especially in the ASEAN regions; Malaysia was the highest secondhighest on international tourist arrivals in 2019 after Thailand. Furthermore, according to Obrien and Jamnia (2013), international students can benefit the local economy in a variety of ways, including

on-campus purchases directly linked to their studies;

off-campus spending on housing, food, books, transportation, clothing, and entertainment; role in contributing to the local tourism industry through domestic travel and other tourist activities; and non-educational spending by visiting friends and relatives (VFR) as well as return visits for alumni.

In turn, international educational tourism may increase sales of products and services, tax income, and job development (Obrien \& Jamnia, 2013). However, a significant decline in international arrivals for tourists in 2020 began when Malaysia confirmed on 25 January 2020 its first COVID-19 case and increased in the number of instances leading to a cancellation of travel and tour operations, as well as the announcement of the closure of international border under the MCO by the Prime Minister of Malaysia. Because of this circumstance, in 2020, Malaysia received only RM 12.69 billion in revenue from 4.33 million international tourists. In 2021, global tourism endured its worst year in Malaysia and the World Tourism Organisation (UNWTO), as foreign arrivals fell $74 \%$ due to a previous decrease in worldwide demand and 
widespread restrictions on tourism. Occasionally, the pandemic has highly impacted Malaysia's travel and tour activities, including the closure of higher institutions, inbound and outbound, under travel restrictions. Hence, this study discusses the importance of understanding the educational tourist behavior in selecting educational tourism destinations among ASEAN postgraduates' students in the public universities in Malaysia. The following sections will examine the critical context of the proposed study from the perspectives of destination selection behavior in educational tourism, motivation facets, and educational tourist and institutional physiognomies.

\section{The Research Gap}

There are four distinctive research gaps derived from the previous scholars related to destination selection behavior in educational tourism, motivation in educational tourism, educational tourist physiognomy, and institutional physiognomy. These research gaps form the basis of inquiries of the problem to be explored. Details of discussions on these research gaps are presented in the following sections.

\section{Destination Selection Behavior in Educational Tourism}

Many studies have been done on the tourism decision-making process for obtaining its products or services and the factors influencing a travel destination's behavior. Previous researchers also considered the single decision of selecting a destination among several dimensions, classified as administrative units such as the image of countries, products and services, macro-destinations of geographical areas, and destination attractiveness (Trimurti \& Utama, 2021). Moreover, Kamb et al (2020) cited that tourists' destination selection is a more complex process that can be studied in various stages, including the decision to vacation, vacation decision abroad, and choose to a destination within a country. According to Tomasi, Paviotti, and Cavicchi (2020), the nations could be more successful if they could integrate the education and tourist industries as a pathway of international interaction and learning. Furthermore, Simkova and Holzner (2014) revealed in the criteria for selecting tourist destinations that the travel patterns of individuals are strongly linked to the psychological habits that may be used to assess the reasons that inspire people to travel and choose a specific destination. In this current study, the behavior of educational tourists who are known for their dynamic magnetism (Ojo \& Yusof, 2019a) and variations in the level of expansion of educational tourism capitals and amenities of countries are studied. According to Becker and Kolster (2012), the educational tourism destination selection process analysts differ from government and individual. The study also reported more research to gain more insight into international educational tourists' outside dimensions. There is the economic and social importance of educational tourism for a destination. The availability of study-international programs offers local individuals greater chances. A study in Malaysia revealed that international students at an educational tourism hub might improve the local people's quality of life by increasing possibilities for local entrepreneurs and offering financial advantages (Shwayat, 2017). Therefore, it is crucial to measure the variables, dimensions, and constructs that regulate educational tourists' behavior when selecting an educational tourism destination. 
DEVELOPMENT

Vol. 10, No. 3, 2021, E-ISSN: 2226-6348 @ 2021 HRMARS

\section{Motivation in Educational Tourism}

Tourism is known as a practice of traveling for pleasure, business, or education (Simkova \& Holzner, 2014). Tourists' personalities, views, values, and ways of life are part of a new experience in meeting people, places, and cultures. Motivation and behavior are also critical elements in defining modes of contact with visitors or communication developing a plan for business support. Based on Krettenauer (2020), motivation is defined as a dynamic process of internal psychological factors, including needs, wants, and goals. Due to the importance of motivation in the tourism context, research on tourists' motivation has a long history with several early works in the 70s, including that by Dann (1977), to more recent decades by Klenosky (2002); Biswas (2008); Ojo and Yusof (2019b) focusing on push and pull factors related to tourists' motivation as well as intrinsic and extrinsic motivation by Deci and Ryan (2008). The relevance of reasonable cost and fee structures is essential in analyzing the criteria for selecting educational tourism destinations. Also, identifying these criteria will help strategies choose the correct tools for educational tourism destination marketers (Ojo \& Yusof, 2019b). Likewise, customer satisfaction, motivation, and functionality of the institution contribute to the scholarly tourism literature by examining the reputation and ranking of the university. Higher education collects substantial consideration, as it is one of the significant revenue generators (Rahimizhian, Avci \& Eluwole, 2020).

Furthermore, the present COVID-19 epidemic has irreversibly altered the globe, significantly influencing international travel, tourism demand, and the hospitality industry (Chang, McAleer, \& Ramos, 2020). As a result, nations worldwide are taking various steps to reduce the effects of the COVID-19 outbreak and urge the tourism and travel industries to recover. Thus, it is critical to investigate better the previous tourism crises and current developments in visitor attitudes and perceptions better to comprehend the changes and features of tourism demand.

\section{Educational Tourist Physiognomy}

Past literature has mentioned the importance of each element in educational tourism connected to sustaining the ecosystem of educational tourism. One of the important reasons is international educational tourist behavior (Ojo \& Yusof, 2020; Alipour, Fatemi \& Malazizi, 2020). According to Alipour et al (2020), educational tourists refer to international students who cross borders for the sole purpose of the study and do not hold the same nationality as the host country. International students also benefit the local economy by spending money on transportation, trips to specific sites, restaurants, and local food while living and studying abroad (Nugroho \& Soeprihanto, 2016). Despite this, most educational tourism studies have focused on why international students opt to study overseas. Other comparatively important factors include educational tourists' attitudes (Rahimizhian et al., 2020). The authors concluded that educational tourists rely heavily on other customers' past experiences and opinions when choosing a destination in educational tourism settings.

Moreover, Alipour et al (2020) stated that in the current pandemic situation, it is crucial to evaluate the consequence of usage and implementation of innovative technologies that help reduce the physical appearance of the educational tourists on campus to endure the sustainability of educational tourism holistically. Future research on visitors' attitudes to tourism destinations is crucial at this time from a tourism management perspective (Hadinejad et al., 2021). Furthermore, the authors highlighted the importance of active participation from an educational tourist point of view, such as satisfaction. Several recent findings showed that 
perceived value is a better indicator of behavioral intention (Rahman et al., 2021). International exchange students are an often-overlooked demographic in tourism research; thus, their choices to return to the host country have not been investigated. In the current scenario, the COVID-19 pandemic has created an environment of psychological fear across all sections of society (Pandita et al., 2021). Based on those cited authors' views, fear is naturally a common emotional reaction by the psychological defensive mechanism to counter any threat. From the arguments, this future study will analyze the effects of emotion on destination selection behavior among ASEAN postgraduates in public universities; the expected outcomes would provide evidence on the readiness to return to campus or stay in the host country.

\section{Institutional Physiognomy}

According to Scotto (2019), physiognomies mean infrequent connotations amid illustrative representations and experience of meaning. In this future study, the institutional physiognomy will also evaluate as moderating variable. Pitman, Broomhall, and Majocha (2011) studied the role of higher education institutions in educational tourism and highlighted that educational tourism is an exciting site of study. From the view of Rahimizhian et al (2020), events and happenings like festivals, celebrations, and sports-related events are significant in determining the factors of an educational institute's quality among students, as they create opportunities for active participation in education-related events. Moreover, Thomson (2002) concluded that good branding would provide a solid indication for existing and future students about the quality and credibility of an institution. These are among the factors identified for enhancing the quality of higher education institutions.

Furthermore, student satisfaction in higher education can increase if the service culture of the university can meet the requirements of educational tourists (Tomasi et al., 2020). Thus, to sustain operations in highly competitive institutions, they must develop a positive reputation, maintain good service quality, enhance students' loyalty without eroding the existing students', and strengthen their alumni engagement. In this study, the researcher will evaluate the effects of educational tourists and institutional physiognomies on destination selection behavior, which has been proposed by Greenwood, Horton, and Ultey (2002) in managing continuous and sustainable training quality (academic staff), ethical aspect (behavior, honesty), and appeal to emotion (trust, recognition) to be included under assessment by students in evaluating the attractiveness of a particular educational institution. Although there has been more comprehensive research on students' satisfaction and loyalty, institutional image, and reputation (Del-Castillo-Feito, Blanco-Gonzalez, \& Delgado-Alemany, 2020), they reckoned that there is still a lack of empirical evidence to clarify the differences and common points as well as the relationship between these variables. Given the above critical perspectives, there would be essential inquiries to be examined in the proposed study to provide the foundation for examining the relationships between educational tourism motivation, educational tourist and institutional physiognomies, and destination selection behavior in the tourism industry.

\section{Purpose of Research and Research Question}

Based on the research gaps, this conceptual paper is intended to identify the links among motivational facets, educational tourist and institutional physiognomies, and 
destination selection behavior of ASEAN postgraduates' students in Malaysia's public universities.

Therefore, the research questions to be addressed are as follows:

i. What are the relationships between motivation facets, educational tourist physiognomy, and educational tourism destination selection behavior in the extended S-O-R model?

ii. Does educational tourist physiognomy mediate the relationship between motivation facets and educational tourism destination selection behavior in the extended S-O-R model?

iii. Does institutional physiognomy moderate the relationship between motivation facets and educational tourism destination selection behavior in the extended S-O-R model?

iv. How does educational tourism destination selection behavior affect the S-O-R model?

\section{Theoretical Overview}

The theoretical foundation of the proposed study is based on the Stimulus-OrganismResponse model developed by Mehrabian and Russel (1974) and later modified into an augmented S-O-R Model that combines with the Self-determination Theory (SDT) by Ryan and Deci (2000) for Educational Tourism in Malaysia. The following sections describe the development of this theoretical overview for the proposed study.

\section{The Stimulus-Organism-Response (S-O-R) Model}

Psychological structures and processes that mediate between stimulus and behavior may be examined using Mehrabian and Russell's (1974) Stimulus-Organism-Response (S-O-R) model. The internal or external environment as stimulus $(S)$ that influence organisms $(O)$ and result in approach or avoidance reaction ( $R$ ) behaviors toward the store, as well as behaviors like store seeking, intention to buy, and repurchase intention, according to Mehrabian and Russell (1974). The S-O-R model's conceptual framework is shown in Figure 1.

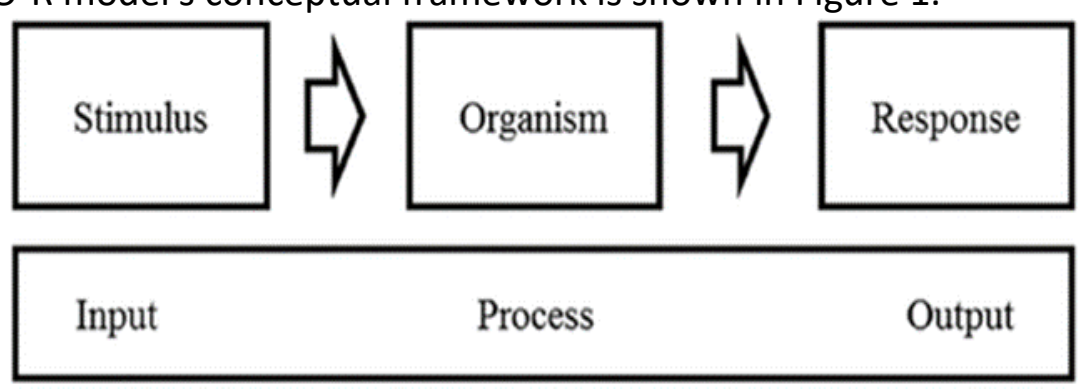

Figure 1: Conceptual framework of S-O-R model

Pandita et al (2021) defined stimulus and response as components of behavior and the environment in their S-O-R model (Figure 1). While rapid changes in the environment may affect an organism's psychological and mental stability, they may also cause behavioral changes (response). The application of good ideas guides this kind of analysis. The S-O-R model has attracted many research areas over the last few decades owing to its intuitive and robust mechanism for studying human behavior (Kim et al., 2020). Emotion, motivation, attitude, and reasoning are other significant scientific notions (constructs) utilized to show intermediation between stimulus and behavior. The S-O-R theory may be a helpful reference system for the idea of personality and subcategories such as education or personality characteristics. 
Furthermore, research suggests that human behavior is not only influenced by the environment, features, or additive environment-trait interactions, but the determination of behavior by additive environment-trait interactions would imply that valid measures of a trait, such as anxiety tests, as well as valid measures of situations that are relevant for a particular feature, are sufficient to predict tourist behavior; in particular, the S-O-R model's specialization on emotion toward surroundings will provide valuable insights in exploring tourist experiences (Chang et al., 2014).

\section{The Self-determination Theory (SDT)}

Self-determination theory (SDT) provides a sound and widely recognized empirical foundation for examining the potential behavioral effects of increasingly popular forms of travel, such as educational tourism. According to Malik (2019), the SDT is a framework for academic research increasingly used to study customer motivation, satisfaction, and future behavior. Thus, the value dimension may be classified into two categories in this study setting: intrinsic and extrinsic incentive. It is projected that if these two types of motivational features are met, educational tourism destination selection behavior will be significantly influenced. The SDT will serve as the empirical theory underpinning the investigation and contributes to the model's expansion. This theory establishes a connection between personality, human motivation, and efficiency. Intrinsic and extrinsic motivation are strong forces in determining human behavior (Deci \& Ryan, 2008). This SDT is an expansion of Deci and Ryan's Motivation Theory (1985). Deci and Ryan (1985) define intrinsic drive as emanating from inside. Intrinsic motivations influence how people behave, including self-core beliefs, interests, and a personal sense of morality.

On the other hand, extrinsic motivation is a desire to perform in particular ways due to external benefits. These include grading systems, personal evaluations, awards, and feelings of affection and respect for an object (Deci \& Ryan, 1985). According to Ryan and Deci's (2008) self-determination theory, humans are rarely motivated by a single sort of motivation. Thus, it is advantageous to examine individuals' motivations along a continuum spanning from nonself-determined to self-determined. Rather than that, it is hypothesized that educational tourist physiognomy and institutional physiognomy are mediated and moderated in the study environment by two aspects of self-determined motivations, resulting in direct and indirect influences on destination selection behavior. The Self-Determination Continuum is depicted in Table 2: 
Table 2: Self-Determination Continuum

\begin{tabular}{|c|c|c|c|c|c|c|}
\hline Behavio & \multicolumn{5}{|c|}{ Non-self-determined } & Self-determined \\
\hline $\begin{array}{l}\text { Type of } \\
\text { Motivati } \\
\text { on }\end{array}$ & Motivation & & Extrinsic & Motivation & & Intrinsic Motivation \\
\hline $\begin{array}{l}\text { Type of } \\
\text { Regulati } \\
\text { on }\end{array}$ & $\begin{array}{l}\text { Non- } \\
\text { regulation }\end{array}$ & $\begin{array}{l}\text { External } \\
\text { Regulatio } \\
n\end{array}$ & $\begin{array}{l}\text { Introjecte } \\
\mathrm{d} \\
\text { Regulatio } \\
\mathrm{n}\end{array}$ & $\begin{array}{l}\text { Identified } \\
\text { Regulatio } \\
\mathrm{n}\end{array}$ & $\begin{array}{l}\text { Integrate } \\
\mathrm{d} \\
\text { Regulatio } \\
\mathrm{n}\end{array}$ & Intrinsic Regulation \\
\hline $\begin{array}{l}\text { What is } \\
\text { the } \\
\text { Source } \\
\text { of } \\
\text { Motivati } \\
\text { on? }\end{array}$ & Impersonal & External & $\begin{array}{l}\text { Somewha } \\
\text { t External }\end{array}$ & $\begin{array}{l}\text { Somewha } \\
\text { t Internal }\end{array}$ & Internal & Internal \\
\hline $\begin{array}{l}\text { What } \\
\text { Regulate } \\
\mathrm{s} \text { the } \\
\text { Motivati } \\
\text { on? }\end{array}$ & $\begin{array}{l}\text { Nonintenti } \\
\text { onal, non- } \\
\text { valuing, } \\
\text { Incompete } \\
\text { nce, Lack } \\
\text { of Control }\end{array}$ & $\begin{array}{l}\text { Complian } \\
\text { ce, } \\
\text { External } \\
\text { Rewards, } \\
\text { and } \\
\text { Punishme } \\
\text { nts }\end{array}$ & $\begin{array}{l}\text { Self- } \\
\text { control, } \\
\text { Ego- } \\
\text { involvem } \\
\text { ent, } \\
\text { Internal } \\
\text { Rewards } \\
\text { and } \\
\text { Punishme } \\
\text { nts }\end{array}$ & $\begin{array}{l}\text { Personal } \\
\text { Importan } \\
\text { ce, } \\
\text { Conscious } \\
\text { Valuing }\end{array}$ & $\begin{array}{l}\text { Congruen } \\
\text { ce, } \\
\text { Awarenes } \\
\text { s, Self- } \\
\text { synthesis }\end{array}$ & $\begin{array}{l}\text { Interest, Enjoyment, } \\
\text { Inherent Satisfaction }\end{array}$ \\
\hline
\end{tabular}

Source: Ryan and Deci (2000)

\section{The Proposed Augmented S-O-R Model for Educational Tourism in Malaysia}

Among tourism research, Jeong et al (2020) cited that the S-O-R model is one of the most suitable frameworks to study the behaviors of tourists by considering the intangible products and services of tourism. The S-O-R model has been implemented in different research frameworks using different research methods and theories to other researchers' knowledge. Moreover, recent studies have investigated the role of emotion in the relationship with stimuli to explore tourist behaviors. The S-O-R model was also utilized in research on sports tourism that looked at the impact of nostalgia (emotions) on visitor behavioral intention (Cho, Chiu \& Tan, 2021). Earlier, Wee (2016) also applied the S-O-R model to event tourism, looking at the impact of festival quality (service performance quality and perceived service quality) on tourist loyalty with emotion as a mediating element. With an increasing number of studies by tourism researchers looking at the impacts of emotion on outcome variables like tourist behavior and behavioral intention, this future study will also utilize the most widely used S-O-R theories in the context of educational tourism in Malaysia. Given previous instances of comparative research, the results may not help predict educational tourist behavior. Thus, the present study will propose another extended S-O-R model by examining the relationship between 
motivational facets (stimuli) adapted from the SDT (Ryan \& Deci, 2000), educational tourist physiognomy (organism), and destination selection behavior (responses).

Additionally, to address gaps in the prior research literature by examining moderating effects in educational tourism, this study will incorporate an external source of information (institutional image) as a critical element in educational tourism destination selection behavior. The present study will provide additional insightful findings by testing a sequential mediation model and incorporating an external source of information based on the S-O-R model. The model will be expanded to examine the effects of educational tourists' motivation facets, educational tourists' physiognomy, and educational tourism destination selection behavior. This proposed study will provide a novel theoretical framework for understanding the relationships among the four constructs: the educational tourist motivation facets, educational tourist and institutional physiognomies, and destination selection behavior. As a result, the current study proposes a comprehensive S-O-R framework, significantly impacting the relevant body of knowledge. Second, the proposed research's findings would allow universities to rethink their strategic plans. Most universities are constantly competing for global rankings, reputation, and image and increasing their internationalization and globalization efforts despite the ongoing global COVID-19 pandemic.

\section{Review of Related Literature \\ Educational Tourism}

UNWTO (2019) described educational tourism as a kind of tourism that includes many different types of tourism linked to tourists' motivations to travel, participate in various training, self-improvement processes, intellectual growth, and the development of varied and diversified skills. In mind, educational tourism encompasses multiple goods and services relating to academic research, skill acquisition vacations, school field excursions, fitness classes, career advancement courses, and language courses. Compared to the 1990s, the internationalization of universities has become an essential element of global higher education. Similarly, Kamdi et al (2016) argued that the increasing number of universities globally caused competition in the higher institutional sector. The competition among higher institutions led to the development of educational tourism as an economic activity that attracted the participation of many countries in the world. The COVID-19 epidemic, on the other hand, has wreaked havoc on the tourist sector across the globe. Governments worldwide are shutting international borders and imposing travel restrictions (Salcedo \& Cherelus, 2020).

Consequently, many international students studying in the educational tourism host country cannot go back to their home country and vice versa throughout this urgent scenario. Those who can return home are worried that their academics may be disrupted. Several measures are now being considered; for instance, institutions all around the globe are urging international students not to go abroad, placing them at risk of infection (Sahu, 2020). As a result, the interruption caused by COVID-19 may impact foreign student admission for the following academic year. However, necessary action should be taken to prepare for a return to normality by examining all aspects. Given the increasing demand for higher education before the outbreak of the COVID-19 pandemic, marketers will need to update their knowledge of educational tourism, institutional and destination-relevant methods to continue attracting significant numbers of international students. 
DEVELOPMENT

Vol. 10, No. 3, 2021, E-ISSN: 2226-6348 ㄷ 2021 HRMARS

\section{Educational Tourism in Malaysia}

As has been widely tourist educational tourist attractions not only impact the region's economy, but they may also provide personal benefits to individuals and the local society. Educational tourism will benefit universities in terms of revenue, comprehensive facilities and expertise, and increased visibility. This was translated when educational tourism in Malaysia was gradually growing in popularity, as the country strives to become a global center for tertiary education, offering high quality and affordable education. Moreover, many factors now affect students' decisions to study abroad. Apart from the lower cost of education in countries like Malaysia and Singapore, English as a medium of instruction and study in most higher education institutions also allows international students from all over the globe to enroll.

Furthermore, the university's worldwide rating becomes a factor in determining whether or not it is a suitable location for international students to study. Malaysia has a $70 \%$ gross higher education enrolment rate, with 1.2 million students enrolled in public and private higher education institutions such as public universities, polytechnics, community colleges, private universities, and private colleges during the past decade. With this growth, Malaysia now ranks third among ASEAN nations for masters and doctoral program enrolment, after Singapore and Thailand, according to the Ministry of Higher Education (MOHE, 2015). With the increase in entering visitors, there is a possibility that the number of entering international students may increase, bringing more tax revenue into local educational institutions. Table 2 shows the total number of international students in higher institutions by country of origin for 2020.

Table 2: International Students in Malaysia's Higher Institutions by Countries of Origin 2020

\begin{tabular}{|c|c|}
\hline Country & Total International Students \\
\hline China & 16,957 \\
\hline Indonesia & 9,983 \\
\hline Bangladesh & 8,338 \\
\hline Yemen & 5,084 \\
\hline Pakistan & 4,973 \\
\hline Nigeria & 4,647 \\
\hline India & 3,206 \\
\hline Egypt & 2,653 \\
\hline Sri Lanka & 2,627 \\
\hline Iraq & 2,160 \\
\hline Others & 35,327 \\
\hline Grand Total & 95,955 \\
\hline
\end{tabular}

Source: Ministry of Higher Education (2021)

According to Table 2, Malaysia has 95,955 international students enrolled in public and private universities. Rapid privatization of higher education in other nations has resulted in low performance. It is widely recognized that the degree to which actual service performance meets the customer's requirements and expectations determines service quality (Kwok et al., 2017). As a result, Malaysia must devise ways to avoid falling into this trap. It is critical to optimize the current plan execution to guarantee that existing institutions stay viable in the 
face of declining foreign student enrolment patterns. Malaysia's overall position as an attractive educational destination at the global and regional levels necessitates ongoing development from public institutions. This kind of effort helps develop the country's tourist businesses, with educational tourism playing a crucial part in maintaining the destination's service quality and appeal, which benefits the company.

\section{Tourist Motivation}

The traveling phenomenon among youth and students has become a fast-growing trend. It is necessary to understand young people's tourist motivations because their demands and desires may lead to specific travel behavior, such as the tourist attractions they choose to visit (Han, Kim, \& Kiatkawsin, 2017). Frost and Shanka (2015) performed another research on student travel motivation and found that the main reasons for students' cheap costs were entertainment, easy access to culture, and historic sites. Each educational tourist has their preferences or motives for travel, as evidenced by motivational differences between students from Japan and the United States (Sakakida, Cole, \& Card, 2004), as well as differences in the travel motivations of Canadian and Chinese students (Wang \& Walker, 2010). Moreover, Kim and Jogaratnam (2002) performed research on student motivations of ASEAN foreign college students and identified seven motives, including knowledge-seeking, relaxing, entertainment, sports, leisure, boasting about travel, and family. When comparing the motivations of ASEAN international college students to those of American students, knowledge-seeking and sports played different roles in motivating students from these two origins, with ASEAN international college students being highly motivated by knowledge seeking to travel, whereas American students preferred sports, relaxation, entertainment, boasting about travel, and family. However, the motive's criterion assessment rejected the idea that culture is represented by a system of principles encompassing individualism or collectivism ( $\mathrm{Vu}$, Maulen, Heslenfeld, Woodcock, Han \& Krabbendam, 2019). Each person's psychological processes and behaviors are structured around attempts to align with a system of practices and public meanings. As a result, the systematic culture perspective refutes that Eastern and Western cultures have fundamentally distinct values. By focusing on intrinsic and extrinsic motivations, a study can examine international students' personnel travel behavior in terms of academic and personal growth, better career prospects, and economic benefits, or they may have an intention to avoid disadvantageous conditions in their home country, which are intrinsic motivations (Mok, Bakac \& Froehlich, 2020). Therefore, those gaps identified in the past studies will be further investigated in the present study.

\section{Tourism Destination Selection Behaviour}

From a psychological point of view, decision-making is defined as a process of human thought and as a reaction to the external world, including a perceptual, emotional, and cognitive function (Simkova and Holzner, 2014). With the recent development of tourism, a continuing understanding of consumer behavior is critical because the strategic management of tourism destinations relies on developing theories about tourist behavior and a sense of destination choice. Furthermore, since destination choice is essential to destination marketing organizations (DMOs), it has long been a prominent study subject in the academic tourism area (Thomas \& Wee, 2016). Thus, the decision of international educational tourists in educational tourism destination selection is determined by intrinsic and extrinsic motivation. Previous studies revealed educational tourists' characteristics, academic learning, and career 
development as an inherent dimension of the decision to study abroad (Mazzarol \& Soutar, 2002; Becker \& Kolster, 2012). In addition, outside dimensions of educational tourists' decision to study overseas include social factors, the economic factors of the home country (Oja \& Yusof, 2020), and the education system in the home country (Mazzarol \& Soutar, 2002).

Further, the decision of destination of choice was observed as a decision made either by an individual or/and joint decision by family members, friends, and significant relative essential can influence the decision-making process (Biswas \& Husain, 2020). Moreover, among the various factors that affect a tourist's destination choice decision, culture remains an essential factor yet to be examined. Based on previous literature, the effect of culture on destination choice is reflected in two aspects. The first is that tourists from different cultural backgrounds behave differently in choosing destinations, and the second is the cultural similarities or differences between them (Liu, 2014). In a theoretical context, Saito and Strehlau (2018) criticized the models proposing the process of decision making in destination selection that is critically focused on internal and external factors. According to the study, there are several ways of understanding the decision-making process and behavior. The critics also went to existing models that mainly consider that the individual's choice process depends only on individual, group, and moment (Saito \& Strehlau, 2018). Usakli and Baloglu (2011) suggested actual models of choice include the role of emotions in the decision-making process in an actual situation. Based on the study, considering the role of emotions in travel destination selection, the influence of the distance is between the tourist's self-image and the image attributed to the destination as a motivating factor. Thus, studying the influence of relatives, cultural and tourist characteristics, travel-related costs, and emotions on a joint decision will be within the scope of this study.

\section{Conceptual Model Development}

The conceptual paper examines the theoretical foundation of the relationship between motivation and destination selection behavior, mediated by educational tourist physiognomy and moderated by institutional physiognomy. A study was conducted on various models developed by multiple authors, as discussed in the theoretical overview section. Thus, the conceptual model shown in Figure 2 combines the S-O-R model of Mehrabian and Russell's (1974) and Self-determination Theory by Deci and Ryan (2008) as an extended model for the study. Therefore, as shown in Figure 2, the study proposed the following propositions:

Hypothesis 1: Motivation facets positively influence educational tourism destination selection behavior in the extended S-O-R model.

Hypothesis 2: Motivation facets positively influence educational tourist physiognomy in the extended S-O-R model.

Hypothesis 3: Educational tourist physiognomy positively influences educational tourism destination selection behavior in the extended S-O-R model.

Hypothesis 4: Educational tourist physiognomy mediates the relationship between motivation facets and educational tourism destination selection behavior in the extended SO-R model.

Hypothesis 5: Institutional physiognomy moderates the relationship between motivation facets and educational tourism destination selection behavior in the extended S-O-R model. Hypothesis 6: There are varying destination selection behavior effects in the S-O-R model. 


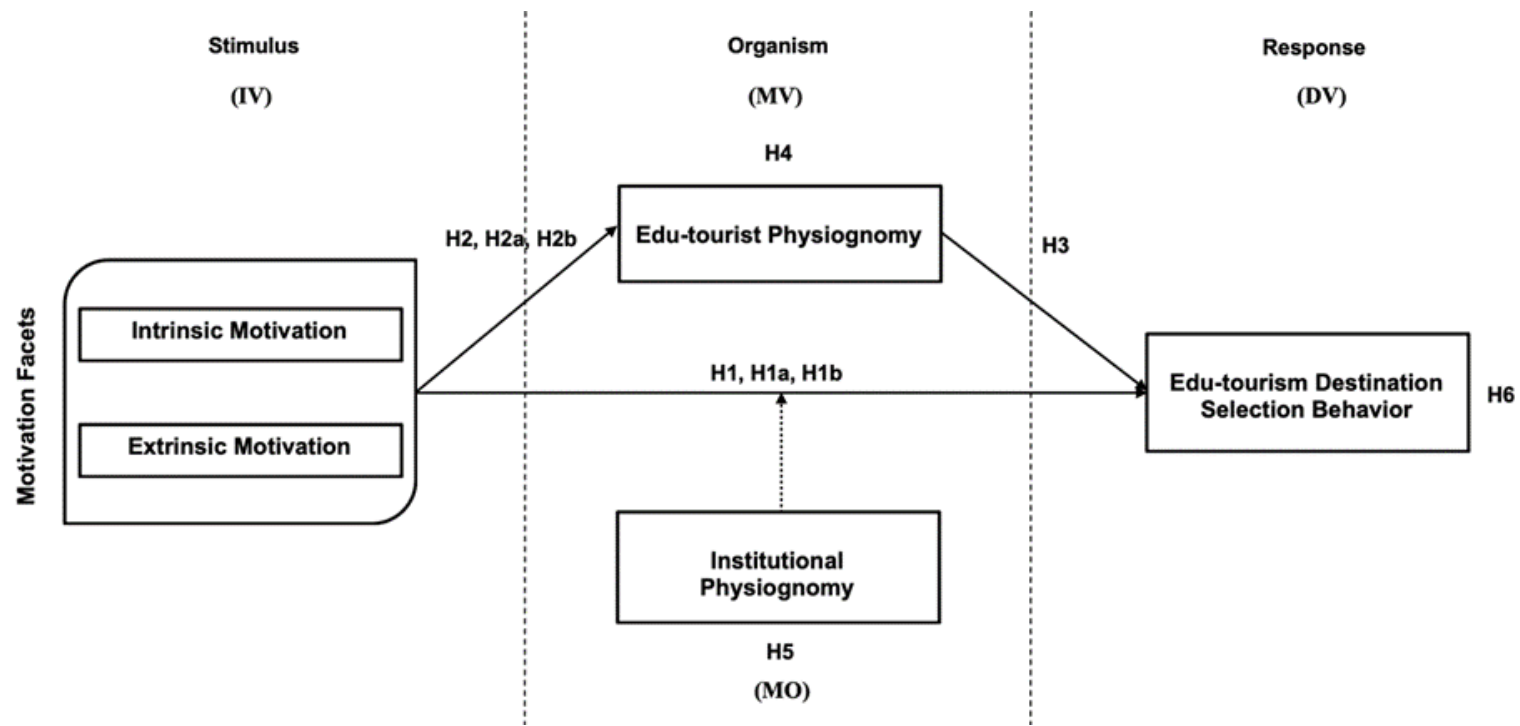

Figure 2: An Augmented S-O-R Model Proposed for the Research

\section{Methods}

The proposed study would conduct a cross-sectional survey to ascertain the association between motivating factors, physiognomies, and destination selection behavior. Given that the suggested hypothesis will be tested using PLS-SEM with SmartPLS, the sample size is decided by the analysis's power and the model's complexity (Hair et al., 2017). This study uses Power analysis and the Roasoft sample size calculator to estimate the sample size for this study, which resulted in a targeted sample of 68 to 339 postgraduates from ASEAN out of a total population of 2867 in Malaysia public universities. On the other hand, Hair, Celsi, Money, and Samouel advocate a sample size of 200-400 as a critical sample size (2015). Primary and secondary data will be collected, and quantitative data will be examined using descriptive statistics such as percentage distribution, mean, and frequency counts. Partial Least SquaresStructural Equation Modeling (PLS-SEM) will be used to explain the suggested augmented SO-R model variables.

\section{Conclusion and Implication for Future Research}

In this proposed study, a new proposed model of educational tourism destination selection behavior is established by adapting and extending a previous S-O-R model with one mediating variable and one moderating variable. Theories are critical in research because they provide a framework for numerous areas of study aimed at the nature of the issue, address potential mechanisms, and recommend several specific actions (McCullagh, 2005). The research framework comprises five constructs, which are independent variables that include intrinsic and extrinsic motivation features. Educational tourism destination selection behavior is the dependent variable. The essential relationship between motivation components and educational tourism destination choosing behavior will be investigated in this study. Importantly, this study investigates the mediation effects of educational tourist physiognomy on the link between motivational components and educational tourism destination selection behavior. The institutional physiognomy's moderating effects on the link between motivation components and educational tourism destination selection behavior will be studied.

Furthermore, evaluating psychological mood has long been a significant field of research. Previous research employing the S-O-R model has validated the educational tourist, 
institutional, and destination perspectives in the suggested study framework. This research will collect the application of many motivational and behavioral theories that may offer a better understanding of educational tourism destination choice behavior to provide a cohesive theoretical framework in the extended S-O-R model. Because of its propensity to be a multi-billion-dollar business in tourist sub-sectors, the educational tourism ecosystem has become one of the most critical topics explored from various perspectives, including the economy, destination, local community, and entrepreneurship. Educational tourism is a movement initiated by an individual or a group with the primary goal of participating in an educational activity. When it comes to travel motivations, psychological actions among passengers have a significant impact on establishing a general desire to visit specific destinations. Besides, the research's proposed motivational model intends to make it easier to locate a better target market, segment the market, and approach marketing channels more successfully.

Based on the research gaps identified in the prior literature, this study will use postgraduate students from the ASEAN region as the unit of analysis in the study setting. In this context, the study's findings will raise awareness of educational tourist demands. The public university administration will develop tactics that will encourage students to study in Malaysia during the post-COVID-19 pandemic and endemic environment. Given the study's purpose to empirically analyze correlations between motivation facets, educational tourism, and institutional physiognomy, and destination selection behavior, it is evident that the current study will employ quantitative research. Furthermore, this methodology is deemed appropriate as the current study framework. The hypotheses are developed from a deductive method. The study uses a top-down approach by beginning with a general approach to narrow it down into a hypothesis, which explicitly tests the prediction about what we expect to happen in the study (Hair et al., 2017). Furthermore, this methodology has been applied successfully in educational tourism (Safakli \& Ihemeje, 2015; Seyidov \& Adomaitiene, 2016; Ojo \& Yusof, 2019b). The data collection will be carried out after the approval on research ethics obtained from the university.

\section{References}

Alipour, H., Fatemi, H., \& Malazizi, N. (2020). Is Edu tourism a sustainable option? A case study of residents' perceptions. Sustainability, 12(15), 5937. http://dx.doi.org/10.3390/su12155937

Becker, R., \& Kolster, R. (2012). International student recruitment: Policies and developments in selected countries. Organization for International Cooperation in Higher Education.

Bernama. (2019). Maszlee: Edutourism is steadily gaining popularity in Malaysia. Malay Mail. https://www.malaymail.com/news/malaysia/2019/11/30/maszlee-edutourismsteadily-gaining-popularity-in-malaysia/1814705

Chang, C. L., \& McAleer, M., \& Ramos, V. (2020). A charter for sustainable tourism after COVID-19. Sustainability, 12(9), 3671. https://doi.org/10.3390/su12093671

Chang, C. H., Shu, S. T., \& King, B. E. M. (2014). Novelty in theme park physical surrounding: An application of the stimulus-organism-response paradigm. Asia Pacific Journal of Tourism Research, 19(6), 680-699. http://dx.doi.org/10.1080/10941665.2013.779589

Cho, H., Chiu, W., \& Tan, X. D. (2021). Travel overseas for a game: The effect of nostalgia on satellite fans' psychological commitment, subjective well-being, and travel intention. Current Issues in Tourism, 24(10). 1418-1423. 
DEVELOPMENT

Vol. 10, No. 3, 2021, E-ISSN: 2226-6348 @ 2021 HRMARS

https://doi.org/10.1080/13683500.2020.1792857

Dann, G. M. S. (1977). Anomie, ego-enhancement and tourism. Annals of Tourism Research, 4(4), 184-194. http://dx.doi.org/10.1016/0160-7383(77)90037-8

Deci E. L., Ryan R. M. (1985). Cognitive Evaluation Theory. In: Intrinsic Motivation and SelfDetermination in Human Behavior. Perspectives in Social Psychology. Springer, Boston, MA. https://doi.org/10.1007/978-1-4899-2271-7_3

Deci, E. L., \& Ryan, R. M. (2008). Self-determination theory: A macro theory of human motivation, development, and health. Canadian Psychology/Psychologies Canadienne, 49(3), 182-185. https://doi.org/10.1037/a0012801

Del-Castillo-Feito, C., Blanco-González, A., \& Delgado-Alemany, R. (2020). The relationship between image, legitimacy, and reputation as a sustainable strategy: Students versus professors' perceptions of higher education. Sustainability, 12(3), 1189. https://doi.org/10.3390/su12031189

Foo, L. P., Chin, M. Y., Tan, K. L., \& Phuah, K. T. (2020). The impact of COVID-19 on the tourism industry in Malaysia. Current Issues in Tourism, 1-5. http://dx.doi.org/10.1080/13683500.2020.1777951

Frost F. A., \& Shanka T. (2015) International Travel Preferences of Graduating Students. In J. C. Chebat \& A. Oumlil (Eds.), Proceedings of the 1998 Multicultural Marketing Conference. Developments in Marketing Science: Proceedings of the Academy of Marketing Science (pp. 192-200). Springer. https://doi.org/10.1007/978-3-31917383-2_34

Greenwood, C. R., Horton, B. T., \& Utley, C. A. (2002). Academic engagement: Current perspectives on research and practice. School Psychology Review, 31(3), 328-349. https://doi.org/10.1080/02796015.2002.12086159

Hadinejad, A., Noghan, N., Moyle, B. D., Scott, N., \& Kralj, A. (2021). Future research on visitors' attitudes to tourism destinations. Tourism Management, 83, 104215. https://doi.org/10.1016/j.tourman.2020.104215

Hair, J. F., Hult, G. T. M., Ringle, C. M., Sarstedt, M., \& Thiele, K. O. (2017). Mirror, mirror on the wall: A comparative evaluation of composite-based structural equation modeling methods. Journal of the Academy of Marketing Science, 45(5), 616-632. https://doi.org/10.1007/s11747-017-0517-x

Hair, J. F., Jr., Celsi, M., Money, A., \& Samouel, P. (2015). The essentials of business research method (3rd ed.). Routledge.

Han, H., Kim, W., \& Kiatkawsin, K. (2017). Emerging youth tourism: fostering young travelers' conservation intentions. Journal of Travel \& Tourism Marketing, 34, 905 - 918.

Jeong, Y., Kim, E., \& Kim, S-K. (2020). Understanding Active Sports Tourist Behaviours in SmallScale Sports Events: Stimulus-Organism-Response Approach. Sustainability 12(19). http://dx.doi.org/10.3390/su12198192

Kamb, A., Lundberg, E., Larsson, J., \& Nilsson, J. (2021). Potentials for reducing climate impact from tourism transport behavior. Journal of Sustainable Tourism, 29(8), 1365-1382. https://doi.org/10.1080/09669582.2020.1855436

Kamdi, N., Jamal, S. A., \& Anuar, F. I. (2018). A preliminary study of Edu-tourist perceived values in Edu-tourism packages. International Journal of Academic Research in Business and Social Sciences, 8(16), 153-162. http://dx.doi.org/10.6007/IJARBSS/v8-i16/5125

Krettenauer, T. (2020). Moral identity as a goal of moral action: A self-determination theory perspective. Journal of Moral Education, 49(3), 330-345. 
DEVELOPMENT

Vol. 10, No. 3, 2021, E-ISSN: 2226-6348 @ 2021 HRMARS

https://doi.org/10.1080/03057240.2019.1698414

Kim, K.-Y., \& Jogaratnam, G. (2002). Travel motivations of Asian international college students. In L. Changchong, K. Chon, H. Q. Zhang \& X. Yanjun (Eds), Tourism Development in the Asia Pacific Region: Worldwide Views and Multidimensional Perspectives (Vol. 1, pp. 354-361). The Hong Kong Polytechnic University.

Kim, M. J., Lee, C. K., \& Jung, T. (2020). Exploring consumer behavior in virtual reality tourism using an extended stimulus-organism-response model. Journal of Travel Research, 59(1), 69-89. https://doi.org/10.1177/0047287518818915

Kwok, S. Y., Jusoh, A., \& Khalifah, Z. (2017). The mediating effects of value on service qualitysatisfaction relationship in the Malaysian tourism industry. International Journal of Business and Society, 18(2), 363-372.

http://www.ijbs.unimas.my/images/repository/pdf/Vol18-no2-paper10.pdf

Liu, H. (2014). Understanding Destination Choice from a Cultural Distance Perspective. (Master's thesis). Retrieved from https://scholarcommons.sc.edu/etd/2668

Mazzarol, T., \& Soutar, G. N. (2002). "Push-pull" factors influencing international student destination choice. International Journal of Educational Management, 16(2), 82-90. https://doi.org/10.1108/09513540210418403

Mehrabian, A., \& Russell, J. A. (1974). An approach to environmental psychology. The MIT Press.

Ministry of Education Malaysia. (2015). Executive Summary Malaysia Education Ministry of Education Malaysia 2015-2025 (Higher Education). https://www.um.edu.my/docs/ummagazine/4-executive-summary-pppm-2015-2025.pdf

Mok, S. Y., Bakac, C., \& Froehlich, L. (2020). My family's goals are also my goals': The relationship between collectivism, distal utility value, and learning and career goals of international university students in Germany. International Journal for Educational and Vocational Guidance, 21, 355-378. https://doi.org/10.1007/s10775-020-09447-y

Nugroho, H. P., \& Soeprihanto, J. (2016). GadjahMada University as a potential destination for Edutourism. In S. Mohd Radzi, M. H. Mohd Hanafiah, N. Sumarjan, Z. Mohi, D. Sukyadi, K. Suryadi \& P. Purnawarman (Eds.), Heritage, Culture and Society: Research Agenda and Best Practices in the Hospitality and Tourism Industry, Proceedings of the 3rd International Hospitality and Tourism Conference, ISOT 2016 (pp. 293-298). CRC Press/Balkema.

Obrien, P. W., \& Jamnia, M. (2013). International educational tourism and regional development in Taiwan: A discussion paper. Pan-Pacific Management Review, 16(2), 163-189. https://www.academia.edu/17446690/

Ojo, B. Y., \& Raja Yusof, R. N. (2019a). The contemporary edu-tourism destination selection process: A structural regression model. Journal of Tourism and Management Research, 4(2), 497-514. http://doi.org/10.26465/ojtmr.2018339524

Ojo, B. Y., \& Raja Yusof, R. N. (2019b). Edu-tourism destination selection process in an emerging economy. Journal of Tourism Management Research,6(1), 45-59. http://doi.org/10.18488/journal.31.2019.61.45.59

Ojo, B. Y., \& Raja Yusof, R. N. (2020). Influence of policy strategies, instruments, and Malaysians' attitude on sustainable Edu-tourist industry in Malaysia. Journal of Tourism, Hospitality and Sports, 14, 26-34.

https://iiste.org/Journals/index.php/JTHS/article/view/27717/28435 
Pandita, S., Mishra, H. G., \& Chib, S. (2021). The psychological impact of covid-19 crises on students through the lens of stimulus-organism-response (SQR) model. Children and Youth Services Review, 120(5). https://doi.org/10.1016/j.childyouth.2020.105783

Pitman, T., Broomhall, S., \& Majocha, E. (2011). Teaching ethics beyond the academy: Educational tourism, lifelong learning, and phronesis. Studies in the Education of Adults, 43(1), 4-17. https://doi.org/10.1080/02660830.2011.11661600

Rahimizhian, S., Avci, T., \& Eluwole, K. K. (2020). Conceptual model development of the impact of higher education service quality in guaranteeing Edu-tourists' satisfaction and behavioral intentions. Journal of Public Affairs, 20(3), e2085.

https://doi.org/10.1002/pa.2085

Rahman, M. M., Haque, A., Suib, F. H., \& Kabir, S. M. H. (2021). Students' learning needs and perceived value in the selection of educational institutions mediated by satisfaction from Edu-tourism context in Malaysia. International Journal of Innovative Research and Publications, 1(1), 12-25. https://doi.org/10.51430/IJIRP.2021.11.002

Ryan, R. M., \& Deci, E. L. (2000). Self-determination theory and the facilitation of intrinsic motivation, social development, and well-being. American Psychologist, 55(1), 68-78. https://doi.org/10.1037/0003-066X.55.1.68

Safakli, O., \& Ihemeje, O. O. O. (2015). Motivation of students studying abroad: Case of foreign students in European University of Lefke (Eul). International Journal of Academic Research in Progressive Education and Development, 4(4), 1-10. http://dx.doi.org/10.6007/IJARPED/v4-i4/1863

Sahu, P. (2020). Closure of universities due to Coronavirus Disease 2019 (COVID-19): Impact on education and mental health of students and academic staff. Cureus, 12(4), e7541. https://doi.org/10.7759/cureus.7541

Saito, C. S., \& Strehlau, V. I. (2018). Tourist destination choice. A bibliometric study. Review of International Business, 13(1), 17-31. https://doi.org/10.18568/1980-4865.13117-31

Sakakida, Y., Cole, S. T., \& Card, J. A. (2004). A cross-cultural study of college students' travel preferences: A value-oriented perspective. Journal of Travel \& Tourism Marketing, 16(1), 35-41. https://doi.org/10.1300/J073v16n01_04

Salcedo, A., \& Cherelus, G. (2020). Coronavirus Travel Restrictions Across the Globe. The New York Times. 1 April 2020, https://www.nytimes.com/article/coronavirus-travelrestrictions.html.

Scotto, C. (2019). "Meaning is a physiognomy": Wittgenstein on seeing words and faces. Nordic Wittgenstein Review, 8(1-2), https://doi.org/10.15845/nwr.v8i1.3487

Seyidov, J., \& Adomaitienè, R. (2016). Factors influencing local tourists' decision-making on choosing a destination: a case of Azerbaijan. Ekonomika, 95(3), 112-127. https://doi.org/10.15388/Ekon.2016.3.10332

Shwayait, M. A. (2017). International Student's Perception toward Educational Tourism at Yarmouk University. Journal of Tourism \& Hospitality, 06(01). http://dx.doi.org/10.4172/2167-0269.1000266

Simkova, E., \& Holzner, J. (2014). The motivation of tourism participants. Procedia-Social and Behavioral Sciences, 159, 660-664. https://doi.org/10.1016/j.sbspro.2014.12.455

Thomas, A., \& Wee, H. (2016). Event Sustainability and Destination Image: Evidence from Malaysia. In M. S. Radzi et al. (Eds.), Heritage, Culture, And Society: Research Agenda and Best Practices in The Hospitality and Tourism Industry (pp. 311-315). CRC Press. 
Thomson, A. (2002). Strong brand is key to recruitment. The Times: Higher Education Supplement.

Tomasi, S., Paviotti, G., \& Cavicchi, A. (2020). Educational tourism and local development: The role of universities. Sustainability, 12(17), 6766. https://doi.org/10.3390/su12176766

Trimurti, C. P., \& Utama G. B. R. (2021). Bali tourism destination structural loyalty model from the consumer behavior perspective. Turkish Journal of Computer and Mathematics Education (TURCOMAT), 12(4), 494-505.

https://papers.ssrn.com/sol3/papers.cfm?abstract_id=3824796

Usakli, A., \& Baloglu, S. (2011). Destination brand personality and behavioral intention: A comparison of first-time and repeat visitors. In M. D. Alvarez, C. A. Genc, B. Hatipoglu, D. Salman, \& D. Unalan (Eds.). Advances in hospitality and tourism marketing and management (pp. 269-274). Bogazici University.

Vu, T., van der Meulen, A., Heslenfeld, D., Woodcock, K., Han, S., \& Krabbendam, L. (2019). Neural responses to affective stimuli across culturally similar and dissimilar situations. Culture and Brain, 1- 26. https://doi.org/10.1007/s40167-019-000821

Wang, X. Y., \& Walker, J. G. (2010). A comparison of Canadian and Chinese university students' travel motivations. Leisure, 34(3), 279-293. https://doi.org/10.1080/14927713.2010.521318

Wee, H. (2016). The mediating role of emotion on the relationship between festival quality and loyalty /Hassnah Wee. In: The Doctoral Research Abstracts. IGS Biannual Publication, 10 (10). Institute of

Graduate Studies, UiTM, Shah Alam.

World Tourism Organization. (2019). International Tourism highlights. https://www.eunwto.org/doi/pdf/10.18111/9789284421152 